\title{
KANCELARIA KONSYSTORSKA W ZABORZE PRUSKIM NA PRZELOMIE XIX I XX WIEKU
}

\section{Organizacja centralnych urzędów administracyjnych}

Kościół katolicki w zaborze pruskim w interesującym nas okresie rozwijał swoją działalność w ramach struktur organizacyjnych określonych bullą $D e$ salute animarum z 1821 r. Obejmowały one metropolię gnieźnieńską i poznańską z diecezją sufraganalną chełmińską oraz dwie diecezje bezpośrednio zależne od Stolicy Apostolskiej: warmińską i wrocławską. W każdej z tych jednostek terytorialnych funkcjonowały centralne urzędy administracyjne, które przeważnie określano mianem ordynariatu lub konsystorza generalnego. Nie w każdym jednak przypadku między ordynariatem i konsystorzem generalnym można postawić znak równości, ponieważ w niektórych diecezjach pod koniec XIX w. oznaczały one dwie osobne instytucje: urząd ordynariusza diecezji (ordynariat) i urząd jego wikariusza generalnego (konsystorz generalny lub wikariat generalny). Proces kształtowania się struktur organizacyjnych konsystorzy generalnych na ziemiach polskich, zainicjowany pod koniec XVIII w., był dość ściśle powiązany ze zmianami politycznymi oraz ze zmianami w dotychczasowym systemie kancelaryjnym, które polegały na zastępowaniu księgi wpisów aktami sprawy i na rozwijaniu nowoczesnej registratury. W zaborze pruskim proces ten we wszystkich diecezjach w zasadzie został zakończony w pierwszej połowie XIX w., a dokładniej po wykonaniu bulli De salute animarum. Należy jednak pamitać, że dotyczył on wyłącznie konsystorzy generalnych (oficjalatów lub wikariatów generalnych), natomiast proces kształtowania się struktur organizacyjnych urzędu ordynariusza (ordynariatu) był nieco dłuższy, a w przypadku archidiec. gnieźnieńskiej i poznańskiej trwał nawet po wprowadzeniu w życie Kodeksu Prawa Kanonicznego z 1917 r.

Fragmentaryczne informacje na temat organizacji centralnych wladz i urzędów administracyjnych oraz ich kancelarii w diecezjach zaboru pruskiego na przełomie XIX i XX w. zawierają m.in. prace: ks. Józefa Nowackiego',

${ }^{1}$ Archidiecezja poznańska w granicach historycznych i jej ustrój, Poznań 1964, s. 206. 
ks. Bolesława Kumora ${ }^{2}$, ks. Stanisława Wilka ${ }^{3}$, ks. Hieronima E. Wyczawskiego $^{4}$. Brak jednak całościowego i wyczerpującego opracowania tej problematyki stanowi, jak się wydaje, wystarczające uzasadnienie dla podjęcia próby, przynajmniej szkicowego jej przedstawienia.

W połączonych unią personalną archidiecezjach gnieźnieńskiej i poznańskiej oprócz konsystorzy generalnych, znajdujących się w stolicach obydwu archidiecezji, od połowy XIX w. funkcjonował ponadto Ordynariat Arcybiskupi (Curia Archiepiscopalis) z siedzibą w Poznaniu, którego działalność zainicjował abp Leon Przyłuski (1845-1865). Początkowo nazywano go Biurem Prezydialnym Arcybiskupa. W jego skład poza ordynariuszem wchodził jeden lub dwóch radców oraz trzej pracownicy kancelarii: sekretarz, registrator i kancelista. Istotną zmianę w jego organizacji wprowadził abp Juliusz Dinder (1886-1890), który opierając się na wzorach niemieckich powołał Radę Ordynariatu (Consilium Ordinariatus). Należeli do niej: arcybiskup jako przewodniczący i trzech członków kapituły metropolitalnej poznańskiej. Wszyscy trzej byli jednocześnie radcami ordynariatu. W $1910 \mathrm{r}$. na mocy postanowień dekretu Kongregacji Konsystorialnej De amotione administrativa ab officio et beneficio curato z 20 VIII 1910 r. wikariusze kapitulni w obydwu archidiecezjach utworzyli sądy administracyjne w składzie 2-4 egzaminatorów i 2-4 konsultorów, które na drodze postępowania administracyjnego wyrokowały o usunięciu $\mathrm{z}$ beneficjum proboszcza nieusuwalnego. Nie wchodziły one w skład struktur konsystorskich, a po obsadzeniu stolicy arcybiskupiej tworzyły osobną sekcję ordynariatu. Kolejnej reorganizacji Ordynariatu Arcybiskupiego w Poznaniu dokonał kard. Edmund Dalbor (1915-1926) w 1925 r. Polegała ona na oddzieleniu od Rady Ordynariatu funkcji administracyjnych oraz na utworzeniu rzeczywistego urzędu administracyjnego arcybiskupa. W gruncie rzeczy było to tylko formalne usankcjonowanie zmian, które stopniowo wprowadzano w jego strukturach organizacyjnych, zwłaszcza w Radzie Ordynariatu i w jego kancelarii, w ostatnich kilkunastu latach. W 1926 r. w skład ordynariatu wchodzili: arcybiskup, dwóch radców ordynariatu, asesor, członkowie Rady Ordynariatu (wiceprzewodniczący i 5 radców), członkowie sądów administracyjnych oraz pracownicy kancelarii (dyrektor i 4 sekretarzy, z których jeden pełnił również obowiązki kapelana arcybiskupa, woźny) ${ }^{5}$.

Zmiany ustrojowe przeprowadzone na początku XIX w. w konsystorzach generalnych gnieźnieńskim i poznańskim zatwierdził abp Marcin Dunin (1830-

${ }^{2}$ Ustrój i organizacja Kościoła polskiego w okresie niewoli narodowej (1772-1918), Kraków 1980.

${ }^{3}$ Archidiecezja gnieźnieńska w II Rzeczypospolitej, Lublin 1987; Ordynariat Arcybiskupi w Poznaniu, „Roczniki Teologiczno-Kanoniczne”, 31 (1984) z. 4, s. 125-136.

${ }^{4}$ Przygotowanie do studiów w archiwacl kościelnych, Kalwaria Zebrzydowska 1989.

${ }^{5}$ Szerzej na ten temat zob. Wilk, Ordynariat, s. 125-136. 
1842), wydając w grudniu 1831 r. instrukcje służbowe dla wyższych i niższych urzędników konsystorskich ${ }^{6}$. Od tego czasu ich zasadnicze struktury organizacyjne aż do 1915 r. pozostały w zasadzie bez zmian. Stopniowo, w zależności od potrzeb, powiększano jedynie liczbę osób zatrudnionych na poszczególnych stanowiskach. Na czele konsystorza stał wikariusz generalny lub oficjał, a w jego skład wchodzili: radcy konsystorscy (2-5), justycjariusz (świecki urzędnik państwowy), obrońca węzła małżeńskiego, notariusz, fiskał, syndyk, asesor, pracownicy kancelarii (dyrektor, kalkulatorzy, registratorzy, kanceliści-pisarze), woźni. Wiele z tych funkcji łączono w jednym ręku, podobnie jak łączono urząd wikariusza generalnego i oficjała. W drugiej połowie XIX w. skład konsystorzy powiększył się poprzez dołączenie grona sędziów i egzaminatorów prosynodalnych oraz cenzorów ksiąg religijnych. W 1915 r. abp E. Dalbor, utworzył w nich osobne sądy dla spraw małżeńskich, które składały się z przewodniczącego, dwóch sędziów, obrońcy węzła małżeńskiego i notariusza. Po wejściu w życie Kodeksu Prawa Kanonicznego abp Dalbor w 1920 r. rozdzielił władzę sądowniczą od administracyjnej ustanawiając osobne Arcybiskupie Sądy Duchowne z oficjałami na czele. Bez zmian natomiast pozostały $\mathrm{w}$ konsystorzach struktury administracyjne, złożone $\mathrm{z}$ urzędów: wikariusza generalnego, radców konsystorskich, pracowników kancelarii, egzaminatorów prosynodalnych i cenzorów ksiąg religijnych. Od tego roku jednak w aktach coraz częściej pojawia się termin „Kuria Biskupia”, używany na określenie dotychczasowego konsystorza. Całkowite dostosowanie struktur władz diecezjalnych do wymogów nowego Kodeksu Prawa Kanonicznego przeprowadził dopiero abp August Hlond (1926-1946), który w 1927 r. zlikwidował Ordynariat Arcybiskupi w Poznaniu, przekazując jego agendy dotychczasowym konsystorzom w Gnieźnie i w Poznaniu, które przemianował na kurie arcybiskupie. Na bazie zaś kancelarii dotychczasowego Ordynariatu Arcybiskupiego w Poznaniu utworzył Kancelarię Prymasowską ${ }^{7}$.

Inną i bardziej rozbudowaną strukturę centralnych urzędów administracyjnych posiadała diec. wrocławska. W $1828 \mathrm{r}$. istniał tam tylko wikariat generalny i konsystorz, podzielony na trzy instancje oraz 8 komisarzy biskupich (oficjałów okręgowych), którzy sprawowali władzę in spiritualibus nad odpowiednimi archiprezbiteratami. Obydwa urzędy posiadały wspólną kancelarię ${ }^{8}$. W następ-

${ }^{6}$ M. F ą k a, Stun prawny Kościola katolickiego $w$ Wielkim Księstwie Poznańskim w latach 1815-1850 w świetle prawa pruskiego, Warszawa 1975, s. 141; por. J. Now a cki, Archidiecezja poznańska w granicach historycznych i jej ustrój, Poznań 1964, s. 206.

${ }^{7}$ Szerzej na ten temat zob. Wilk, Ordynariat, s. 134-135.

${ }^{8}$ Catalogus Cleri almae Dioecesis Wrotislaviensis sub ditione Serenissimi et Potentissimi Borussorum Regis complectens Ecclesiam Cathedralem, Reverendissimum Vicariatus Generalis Officium, Reverendissimurn Consistorium et tam in cura animarum existentes, quam alios Presbyteros et Superiores Monasteriorum, Wratislaviae 1828, s. 5-7. 
nych latach nastąpiła rozbudowa i stabilizacja struktur organizacyjnych. Na początku drugiej połowy XIX w. w urzędach diecezjalnych występują już dobrze zorganizowane: 1) Tajna Kancelaria Książęco-Biskupia, w skład której wchodziło 7 radców, sekretarz, 2 pisarzy-kancelistów, registrator i woźny; 2) Książęco-Biskupi Wikariat Generalny, w którym oprócz wikariusza generalnego zatrudnieni byli radcy duchowni (7) i świeccy (2), asesor i 3 sekretarzy; 3) Książęco-Biskupi Konsystorz albo Sąd Małżeński z oficjałem na czele, również podzielony na trzy instancje, posiadające własny personel urzędniczy (2-5 radców-sędziów, obrońca węzła małżeńskiego, sekretarz), przy czym konsystorz I instancji określany był mianem oficjalatu. Struktury te uzupełniała komisja do zarządu majątkiem, wspólna dla wikariatu generalnego i konsystorza kancelaria, w której oprócz dyrektora zatrudnieni byli tłumacz, rendant, kalkulatorzy (2), registratorzy (2), pisarze kanceliści (3) i woźni (2), osobna kasa biskupstwa, grupa egzaminatorów prosynodalnych oraz komisarzy biskupich ${ }^{9}$. Tak zorganizowane struktury administracyjne przetrwały w zasadzie do wprowadzenia w życie Kodeksu Prawa Kanonicznego. Przed 1910 r. z nazw wikariatu generalnego i konsystorza biskupiego usunięto określenia „książęco-biskupi", rozdzielono ich kancelarie oraz zwiększono ilość personelu zatrudnionego w kancelarii wikariatu generalnego (6 kalkulatorów, 3 registratorów, 5 pisarzy-kancelistów, 3 woźnych, w tym jeden do noszenia akt ${ }^{10}$.

$\mathrm{W}$ diecezji chełmińskiej $\mathrm{w}$ drugiej połowie XIX i na początku XX w. istniały dwie odrębne instytucje: wikariat generalny i konsystorz generalny, ale na ich czele stał wikariusz generalny i oficjał w jednej osobie, pracowali w nich ci sami radcy (5), justycjariusz (syndyk), a tylko w konsystorzu dodatkowo występował obrońca węzła małżeńskiego. Obydwie instytucje posiadały też wspólną kancelarię biskupią, w skład której wchodzili: dyrektor (sekretarz biskupa), 2-3 sekretarzy-kalkulatorów, 2-3 pisarzy-kancelistów, registrator i woźny. Podobnie jak w diecezji wrocławskiej istnieli komisarze biskupi (28) oraz osobna kasa biskupia i grono egzaminatorów prosynodalnych ${ }^{11}$.

Administracja diec. warmińskiej na przełomie XIX i XX w. ograniczona była tylko do wikariatu generalnego (konsystorza) we Fromborku, na czele którego stał wikariusz generalny i oficjał w jednej osobie. W jego skład wchodziło 3 konsultorów, 2 sędziów w sprawach małżeńskich, obrońca węzła małżeńskiego oraz kolegium egzaminatorów prosynodalnych i cenzorów ksiąg

${ }^{9}$ Schematismus des Bisthums Breslau und seines Delegatur-Bezirks fïr das Jahr 1869, Breslau 1869 , s. 9-11.

${ }^{10}$ Por., Schematismus ... für das Jahr 1895, Breslau 1895, s. 9-10; Handbuch des Bistums Breslau ... für das Jahr 1910, Breslau 1910, s. 10-12.

${ }^{11}$ Zob. Consignatio totius cleri saecularis et regularis ... dioecesis Culmensis sub finem mensis Octobris anni 1870, Gedani 1870, s. 5-6; Schematismus des Bistums Culm 1904, Pelplin 1904, s. 2628; Schematismus des Bistums Culm 1906, Pelplin 1906, s. 26-27. 
religijnych. W kancelarii (in curia Episcopali) natomiast zatrudnionych było 2 sekretarzy i kapelan biskupa ${ }^{12}$.

Każda diecezja posiadała urzędowy organ diecezjalny (miesięcznik), wydawany przez konsystorz i redagowany z reguły przez oficjała (wikariusza generalnego). W archidiec. gnieźnieńskiej i poznańskiej był nim Kościelny Dziennik Urzędowy dla Archidiecezji Gnieźnieńskiej i Poznańskiej (w języku polskim i niemieckim); w diec. chełmińskiej: Amtliches Kirchenblatt für die Diözese Culm; w diec. warmińskiej: Pastoralblatt für die Diözese Ermland i w diec. wrocławskiej: Verordnungen des Fürstbischöflichen General-Vicariat-Amtes zu Breslau $^{13}$. Do ich prenumeraty zobowiązane były wszystkie dozory kościelne i rządcy parafii, a w archidiec. gnieźnieńskiej i poznańskiej wszyscy duchowni ${ }^{14}$.

\section{Pracownicy konsystorza i jego kancelarii}

Za działalność konsystorza i kancelarii oraz za pracowników odpowiedzialny był przed ordynariuszem wikariusz generalny (oficjał). On organizował, kierował i kontrolował pracę w konsystorzu. Zakres pracy w konsystorzu zależał głównie od zakresu kompetencji przyznanego wikariuszowi generalnemu (oficjałowi) przez ordynariusza. Na stanowiskach merytorycznych (radców konsystorskich) z zasady zatrudniani byli duchowni, najczęściej członkowie kapituł katedralnych lub kolegiackich, posiadający odpowiednie przygotowanie teoretyczne i praktyczne. Radcy konsystorscy zajmowali się wszystkimi sprawami z powierzonych im dekanatów, poza oczywiście, personalnymi. Sprawy jednego dekanatu określano mianem decernatu. Każdy z radców, w zależności od pełnienia dodatkowych funkcji, przeważnie zajmował się sprawami od 3 do 6 lub 8 decernatów. Taka organizacja pracy istniała w konsystorzach do chwili ich zreformowania i przemianowania na kurie biskupie. Decernaty zostały wówczas zastąpione referatami, które obejmowały pokrewne sprawy, ale z terenu całej diecezji, np. referat katechetyczny, budowlany, itp. Sprawami personalnymi, zwłaszcza translokacji duchownych, z reguły zajmował się sam wikariusz generalny.

Struktury organizacyjne kancelarii konsystorskich we wszystkich diecezjach były w zasadzie podobne, chociaż różniły się w drobnych szczegółach dotyczących, np. nazw stanowisk czy ilości zatrudnionych osób. Pracą w kancelarii kierował dyrektor, późniejszy kanclerz, który miał do pomocy kilku

${ }^{12}$ Por. Elenchus universali cleri nec non sororum piarum Congregationum dioecesis warmiensis 1897; Elenchus ... warmiensis 1906.

${ }^{13}$ Por. B. Kumor, Ustrój i organizacja Kościota polskiego $w$ okresie niewoli narodowej (1772-1918), Kraków 1980, s. 230-232.

${ }^{14}$ Por. T. Trzcińsk i, Zbiór ustaw archidiecezji gnieźnienskiej i poznańskiej, Poznań 1906, s. $22-23$. 
sekretarzy (kancelistów), kalkulatorów, rendanta, registratora (archiwistę) i siły pomocnicze: woźnego, gońca, czy specjalną osobę do noszenia akt ${ }^{15}$. Na stanowiskach urzędniczych zatrudniano osoby świeckie, nawet kobiety. Większa liczba osób zatrudnionych na stanowiskach kalkulatorów potrzebna była do obliczania kontraktów dzierżawnych, przygotowywania tzw. etatów, czy obliczania szportli (5\% od sum przekazywanych za pośrednictwem konsystorza). Kasa z reguły stanowiła osobną instytucję i znajdowała się we wszystkich diecezjach. Dla archidiec. gnieźnieńskiej wszystkie ważniejsze rozliczenia prowadziła kasa konsystorska w Poznaniu. W każdym konsystorzu zazwyczaj w miesiącach letnich: lipcu i sierpniu większa część pracowników udawała się na urlopy. W archidiec. gnieźnieńskiej i poznańskiej od $1871 \mathrm{r}$. okres tzw. ferii konsystorskich trwał od 20 lipca do 20 sierpnia, z niewielkimi odchyleniami w poszczególnych latach. Duchowieństwo obydwu archidiecezji zostało zobowiązane, aby w tym okresie zwracać się do konsystorzy, jedynie w tych sprawach, które wymagały szybkiego załatwienia ${ }^{16}$.

\section{Obieg pisma}

Wpływające do konsystorza pismo dyrektor zaopatrywał w prezentę, składającą się najczęściej tylko z daty wpływu i numeru dziennika podawczego, a następnie kierował je do odpowiedniego radcy względnie do registratury, jeśli należało dołączyć acta anteriora (wcześniejsze pisma w tej sprawie). Radca na marginesie tego samego pisma redagował koncept decyzji. Po podcyfrowaniu go przez czynnik dekretujący, w tym przypadku wikariusza generalnego, koncept stawał się minutą i przesyłano ją do mundowania, czyli do sporządzenia czystopisu. Czasami decyzję przesyłano zainteresowanemu na tym samym piśmie lub też odsyłano je do ordynariatu. W takich przypadkach w aktach pozostawał ślad w postaci osobnych formularzy, na których odnotowywano, komu i kiedy „dekretem od ręki” przesłano decyzję, pismo czy akta. Po opracowaniu konceptu przez radcę konsystorskiego na osobnej karcie, zamieszczano na niej ten sam numer dziennika podawczego, który otrzymało pismo wpływające. Jeśli natomiast wikariusz generalny wszczynał jakąś sprawę, wówczas pismo to otrzymywało kolejny numer dziennika podawczego.

\section{Forma zewnętrzna akt}

Po zakończeniu poszczególnych spraw akta składano w archiwum (registraturze), gdzie przydzielano im odpowiednie określenia dotyczące ich cha-

${ }^{15}$ Zob. np. Handbuch des Bistum Breslau ... für das Jahr 1910, s. 12.

${ }^{16}$ Tamże, s. 21-22. 
rakteru (generalia lub specialia) i dołączano do woluminu zawierającego akta o podobnym charakterze. Na okładce lub na specjalnie wklejonej karcie dopisywano numery tych akt, które po zszyciu akt w osobny fascykuł (wolumen) przekreślano.

W kancelariach konsystorskich zwracano baczną uwagę na formę zewnętrzną wpływających pism o czym świadczą dość częste upomnienia kierowane pod adresem duchowieństwa ${ }^{17}$. W myśl obowiązujących norm pismo skierowane do konsystorza powinno być sporządzone na całym arkuszu (format A4) i powinno dotyczyć tylko jednej sprawy. Nie wolno było pisać na półarkuszach, na kartach pocztowych i na papierze listowym. Nie mniej ważne było rozmieszczenie tekstu. $\mathrm{Z}$ prawej strony u góry należało umieścić datę, na środku karty nagłówek, a z lewej strony określenie przedmiotu, tzn. jakiej sprawy dotyczy dane pismo, lub datę i numer pisma na które odpowiada. Treść należało pisać na jednej połowie karty (pagina fracta), pod którą po prawej stronie na dole karty winien się znajdować podpis petenta. Wolną przestrzeń między treścią pisma a podpisem należało zakreślić w formie przekreślonej dużej litery $Z$. Adres umieszczano na dole po lewej stronie karty. Warto dodać jeszcze $\mathrm{i}$ to, że w interesującym nas okresie w zaborze pruskim językiem urzędowym był język niemiecki, ale konsystorze archidiecezji gnieźnieńskiej i poznańskiej prowadziły korespondencję urzędową w tym języku, w jakim interesanci zwracali się do konsystorzy ${ }^{18}$.

Akta konsystorzy gnieźnieńskiego i poznańskiego charakteryzują się licznymi szczegółowymi notami kancelaryjnymi o charakterze merytorycznym i formalnym. Wśród not merytorycznych, oprócz konceptów decyzji, występują polecenia służbowe: ad acta, acta anteriora, na sesję ordynariatu, odpis (zaznaczonego fragmentu), reprodukować (w podanym terminie). Wśród not o charakterze formalnym, oprócz wspomnianej już prezenty, znajdują się ponadto adnotacje zawierające datę wpływu do kancelarii, mundowania, ekspediowania oraz ewentualnego reprodukowania. Zazwyczaj umieszczano je na dole na środku karty. $Z$ czasem odręczne pismo zastąpiono specjalną pieczątką zawierającą rubryki: wpł., mund., exp., repr., które uzupełniano odpowiednią datą. Charakter not kancelaryjnych nadawcy pisma posiadają ukośne lub pionowe pojedyncze, podwójne lub potrójne kreski na marginesie pisma lub pojedyncze z kolejną cyfrą arabską. Oznaczają one dołączone do pisma załączniki (alegaty).

${ }^{17}$ Tamże, s. 7-8; por. „Kościelny Dziennik Urzędowy dla Archidiccezji Gnieźnieńskiej i Poznańskiej”, 31 (1916) s. 105; 32 (1917) s. 67-68.

is Trzciński, dz. cyt., s. 15. 